\title{
大江宏の記述の「うち」に関する言説について STUDY ON THE DISCOURSES ABOUT “UCHI” IN HIROSHI OHE'S DESCRIPTIONS
}

\author{
秦 明日香 ${ }^{* 1}$, 河内浩志 ${ }^{* 2}$, 上野友輝 ${ }^{* 3}$, 冨久亜以*4 \\ Asuka HATA, Hiroshi KOUCHI, Yuki UENO \\ and Ai TOMIHISA
}

\begin{abstract}
The purpose of this paper is to clarify the descriptions of Hiroshi Ohe's "Uchi". "To be able to dwell in trust" is to feel the sense of distance in the spatial behaviors and pathways of the entrance, and to gain a sense of security isolated from the outside. The structure of "Uchi”, which is related to Soto and Separation, is expressed as a characteristic of Japanese housing called "in trust" that includes all Body-Mind (physical and mental) aspects. We positioned "Uchi” which is able to dwell in trust as the nature of Japanese dwelling.
\end{abstract}

Keywords : Hiroshi Ohe, Uchi(Hiragana), uchi(Chinese characters), Distance, Body (Body=Mind), Ai(Ma) 大江宏，うち，内，隔て，身体，間

\section{1.はじめに}

\section{1-1. 大江宏と「うち」への注目}

大江宏 (1913-1989) 注1) は，近現代において多くの能楽堂を手掛 けている中で, 日本の伝統様式の本質に目を向けながら, 独自の建 築論を展開した建築家である注 2 。大江は, 生涯において数々の建築 作品を遺しただけでなく, 研究や教育を建築と切り離せないものと 考え, 研究者・教育者としても活躍し, 独自の建築思想を述心゙た数々 の記述・対談も遺している注 3 )。また, 大江は, 当時の建築スタイル として主流となっていた近代建築に対して, 近代建築の特質を, 合 理性, 機能性, 整合性であると捉え, 建築の必要条件とし認めつつ も, 同時に, その特質だけが先鋭化し,「建築が最も大切にしなけれ ばならない本領としての何か」が欠けている危機感も感じていた注4)。 そして大江は, そのような近代建築に対し, 日本近代建築の歴史の 中で, ヨーロッパで始まったモダニズムの理念を日本の伝統の中で 再定義しようとした建築家として, 重要な人物である。

これまでに筆者らは，大江の記述における「間」に関する言説に 着目し, 彼の言説の意味の構造化を行ってきた注5)。その結果, いく つかの「間」の特徵と, 大江にとって「間」は, 建築の設計として の制作思想へと展開していること, 近代建築に欠けている何かとし て重要な鍵語であることが明らかになった注6)。「うち」の用語は, このような大江の思想の鍵語である「間」に関する言説に含まれて おり,「うち」は, 大江の重要な建築制作思想である「間」と連関す る可能性が見いだされた。しかし,「うち」の意味の特徽や, 位置づ けは明らかにされていない。対象資料から抽出された「うち」に関 する言説は，「建築の本質」が執筆された 1962 年が初出であり，以
降，1974 年の「内と外-浜田家三越店」，1984 年の「気配の美学」， 「ものづくりの初心」などにみられる。この中でも特に,「建築の本 質」と「内と外-浜田家三越店」では「らち」が括弧で強調されて用 いられていた注7)。記述の数としては少ないが，この 2 つの論考は， 大江本人の監修で自身の論考が再編された『建築作法一混在併存の 思想から』に再掲されていることから，大江にとって晚年まで変わ らず思想の根底にあった，重要なものであるといえよう。

ここで対象資料とは，大江によって執筆され雑誌等に掲載された 論考や，大江の対談・インタビュー記事等である。大江の記述は， 『新建築』や『建築文化』, 『国際建築』, 『ディテール』, 『建築家』, 『日本建築家協会ニュース』といった建築雑誌を中心に掲載される。 これらの論稿は, 大江の発表した論稿や対談等の内容が緾められた 『建築作法-混在併存の思想から』注8)や『大江宏対談集 建築と気 配』注9) において再掲載され，また『日本の建築家 4 大江宏 間あい の創造』注10)においても, 対談等が纏められている。本研究では, これらを含む大江の著書を対象資料として利用した。

また, 大江の「うち」に関わる研究としては, 真木利江, 加藤駿 両氏による研究が挙げられる集11)。この研究は, 建築作品の中に「う ち」と建築の構成の関わりを作品研究の視点から明らかにしており, 大江の「うち」への注目がうかがえる。

\section{1-2. 主題・目的・進め方・既往研究}

これらの理由から, 大江に着目し, 彼の建築思想の一端である「う ち」の思想とその重要性を明らかにすることを試みる。よって，本 研究では, 主題を「大江宏の記述の「うち」に関する言説について」 として，大江が用いる「うち」の意味に着目し，言説注12)の整理・
*1 石川工業高等専門学校建築学科 助教 · 修士 (環境学)

*2 広島工業大学環境学部建築デザイン学科 教授・博士 (工学)

*3 広島工業大学環境学部建築デザイン学科 助教・博士 (工学

*4 福井大学大学院工学研究科 博士後期課程 - 修士 (環境学)
Assist Prof, National Institute of Technology, Ishikawa College, MEnv, Prof., Dept. of Architectural Design, Hiroshima Institute of Technology, Dr.Eng. Assist. Prof., Dept. of Architectural Design, Hiroshima I.T., Dr.Eng.

Doctoral Student, Graduate School of Engineering, University of Fukui, M.Env. 
Table1 Targeted documents and descriptions about "Uchi"

\begin{tabular}{|c|c|c|c|c|c|c|}
\hline & \begin{tabular}{|l|} 
出版年 \\
/Publish
\end{tabular} & 書名/Title & 種別/Type & 出版社/Publisher & $\begin{array}{l}\text { jち } \\
\text { /Uchi }\end{array}$ & $\begin{array}{c}\text { 内 } \\
\text { /uchi }\end{array}$ \\
\hline 1 & 1968 & \begin{tabular}{|l} 
現代建築家シリーズ フィリップ•ジョンソン \\
/Contemporary Architect Series Philip Johnson
\end{tabular} & \begin{tabular}{|l} 
共著 \\
/Joint work
\end{tabular} & $\begin{array}{l}\text { 美術出版社 } \\
\text { /Bijutsu Shuppan-Sha }\end{array}$ & $x$ & O \\
\hline 2 & 1973 & $\begin{array}{l}\text { 現代日本建築家全集第12巻 浦辺鎮太郎·大江宏/Contemporary Japanese } \\
\text { Architects Complete Volume } 12 \text { Shizutaro Urabe, Hiroshi Ohe }\end{array}$ & \begin{tabular}{|l} 
共著 \\
/Joint work
\end{tabular} & \begin{tabular}{|l} 
三一書房 \\
/San-ichi Publishing
\end{tabular} & O & O \\
\hline 3 & 1976 & 建築の心と技/Heart and skill of architecture & \begin{tabular}{|l} 
共著 \\
/Joint work
\end{tabular} & $\begin{array}{l}\text { 新建築社 } \\
\text { /Shinkenchiku-sha }\end{array}$ & $x$ & $x$ \\
\hline 4 & 1976 & 建築をめぐる回想と思索/Reminiscence and thought over architecture & \begin{tabular}{|l|l} 
共著 \\
/Joint work
\end{tabular} & $\begin{array}{l}\text { 新建築社 } \\
\text { /Shinkenchiku-sha }\end{array}$ & $x$ & O \\
\hline 5 & 1980 & 建築を教えるものと学ぶもの/Teaching and learning architecture & \begin{tabular}{|l|} 
共著 \\
/Joint work \\
\end{tabular} & \begin{tabular}{|l} 
鹿島出版会 \\
/Kajima institute publishing
\end{tabular} & $x$ & $x$ \\
\hline 6 & 1981 & 遺稿小能林宏城/Postscript bu Hiroki Onobayashi & \begin{tabular}{|l|} 
共著 \\
/Joint work \\
\end{tabular} & $\begin{array}{l}\text { 私家版 } \\
\text { /Private edition }\end{array}$ & $x$ & O \\
\hline 7 & 1982 & $\begin{array}{l}\text { 新建築学大系第一巻 建築概論 } \\
\text { /New architecture academy Volume } 1 \text { Introduction to architecture }\end{array}$ & \begin{tabular}{|l} 
共著 \\
/Joint work
\end{tabular} & $\begin{array}{l}\text { 彰国社 } \\
\text { /Shokokusha publushing }\end{array}$ & O & $\mathrm{O}$ \\
\hline 8 & 1984 & \begin{tabular}{|l} 
別冊新建築·現代日本建築家シリーズ8 大江宏/Separate volume Shinkenchiku \\
contemporary Japanese architect series 8 Hiroshi Ohe
\end{tabular} & \begin{tabular}{|l} 
共著 \\
/Joint work
\end{tabular} & $\begin{array}{l}\text { 新建築社 } \\
\text { /Shinkenchiku-sha }\end{array}$ & $x$ & O \\
\hline 9 & 1984 & 大江宏 $=$ 歴史意匠論/Hiroshi Ohe = Historical design theory & \begin{tabular}{|l} 
共著 \\
/Joint work
\end{tabular} & $\begin{array}{l}\text { 大江宏の会編 } \\
\text { /Meeting of Hiroshi Ohe }\end{array}$ & $\mathrm{O}$ & O \\
\hline 10 & 1984 & $\begin{array}{l}\text { 世界建築設計図集7 国立能楽堂·大江宏/World Architectural Design } \\
\text { Collection } 7 \text { National Noh Theater, Hiroshi Ohe }\end{array}$ & - & $\begin{array}{l}\text { 同朋舎 } \\
\text { /Dohosha printing }\end{array}$ & $x$ & O \\
\hline 11 & 1985 & $\begin{array}{l}\text { 日本の建築家4 大江宏 間の創造 } \\
\text { /Japanese architect } 4 \text { Hiroshi Ohe Creating Ai }\end{array}$ & \begin{tabular}{|l} 
共著 \\
/Joint work
\end{tabular} & $\begin{array}{l}\text { 丸善 } \\
\text { /Maruzen }\end{array}$ & $x$ & O \\
\hline 12 & 1987 & $\begin{array}{l}\text { 日本建築画像大系1 木から教えられてつくる/Japanese architectural image } \\
\text { system } 1 \text { made by teaching from the tree }\end{array}$ & $\begin{array}{l}\text { ビデオテープ } \\
\text { /VHS }\end{array}$ & $\begin{array}{l}\text { 早稲田大学出版部/Waseda } \\
\text { University Publishing department }\end{array}$ & - & - \\
\hline 13 & 1989 & $\begin{array}{l}\text { 建築作法 混在併存の思想から/Kenchiku Sappo From the idea of Mixed } \\
\text { coexistence }\end{array}$ & $\begin{array}{l}\text { 大江宏 } \\
\text { /Hiroshi Ohe }\end{array}$ & 思潮社/Shityosya & $\mathrm{O}$ & O \\
\hline 14 & 1989 & 大江宏対談集 建築と気配/Architecture and Sign & $\begin{array}{l}\text { 大江宏 } \\
\text { /Hiroshi Ohe }\end{array}$ & 思潮社/Shityosya & O & O \\
\hline
\end{tabular}

Table2 Targeted first documents about "Uchi”

\begin{tabular}{|c|c|c|c|}
\hline \begin{tabular}{|l|} 
出版 \\
/Publish \\
\end{tabular} & 論考/Title & 掲載/Publisher & Table1 \\
\hline 1962.9 & $\begin{array}{l}\text { 建築の本質 } \\
\text { /Essence of Architecture }\end{array}$ & $\begin{array}{l}\text { 建築文化 } \\
\text { /Architectural Culture }\end{array}$ & 2,13 \\
\hline 1974.2 & $\begin{array}{l}\text { 内と外－浜田家三越店 } \\
\text { /Inside and Outside - Hamada's } \\
\text { Mitsukoshi store }\end{array}$ & $\begin{array}{l}\text { 商店建築 } \\
\text { /Monthly magazine of } \\
\text { store design }\end{array}$ & 13 \\
\hline 1982.6 & 総論 /General Remarks & $\begin{array}{l}\text { 新建築学大系第一巻 建 } \\
\text { 築概論/ } \\
\text { New architecture } \\
\text { academy Volume } 1 \\
\text { Introduction to } \\
\text { architecture }\end{array}$ & 7 \\
\hline 1984.8 & $\begin{array}{l}\text { 気配の美学 } \\
\text { /The aesthetics of the sign }\end{array}$ & 風声第18号/Husei 18 & 14 \\
\hline 1984.9 & $\begin{array}{l}\text { ものづくりの初心/The original } \\
\text { spirit of manufacturing }\end{array}$ & $\begin{array}{l}\text { 季刊アプローチ第87号 } \\
\text { /Quarterly approach } 87\end{array}$ & 14 \\
\hline 1984.10 & $\begin{array}{l}\text { 歴史意匠の再構築 } \\
\text { /Reconstruction of historical } \\
\text { designs }\end{array}$ & $\begin{array}{l}\text { 大江宏=歴史意匠論 } \\
\text { /Hiroshi Ohe = Historical } \\
\text { design theory }\end{array}$ & 9 \\
\hline
\end{tabular}

分析・解釈を試みることを目的とした注13)。研究の進め方は, 収集 した資料のうち,「うち」に関する大江の記述から関係箇所を抽出・ 整理した後に, 内容を分析し, その意味の解釈・構造化を行う注14)。

「うち」に関わる言説を抽出するにあたって, 大江の著作を整理 し，単語の有無を示したものが Table 1である注15)。大江の記述で は, 平仮名表記の「うち」の他に, 漢字表記の「内」が用いられる。 「うち」と「内」の両単語が用いられる大江の記述があることや, 意味を強調するように括弧を用いて表記している記述があることか ら, 本稿では,「うち」と「内」は異なる単語として报う。しかし, 「内」は，「うち」に関わる語である。Table 1 には「内」の有無も 示し，「内」の意味を明らかにするために用いた資料を明示した。
また，Table 1 の著書には，過去の大江の論稿や対談等の内容が 䌂められたものが含まれるため, Table 1 から, 本研究の主題であ

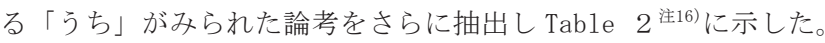

大江に関する既往研究は, 崔康勲氏による一連の大江研究をはじ めとして，少なからずみられる。崔康勲氏による大江研究では，言 説に関わる非常に精緻で興味深い建築論研究として, 大江に関る建 築論の方法の研究等がなされている。崔氏の研究では，建築家・大 江宏によって語られた言葉から，「近代主義者（モダニスト）である ことと近代建築（モダン・アーキテクチュア）を越えようとするこ ととの差異, あるいは建築家・大江宏によって把握されていたとこ ろの近代主義者, 近代建築の概念規定を明らかに」しょうする, 建 築思想の深層への方向が示されている注17)。また，新しいものとし ては, 石井翔太氏らによる「「混在併存」を基軸とする大江宏の建築 観の変遷」注18) が挙げられる。おもに「混在併存」に着目し，言説 研究により大江が各年代で重視していたものは何か，大江の建築観 の変遷を明らかにした研究である。これらの論稿は，本研究におい ても示唆的である。本研究では, これらの研究をふまえ, 特に「う ち」に関する言説の意味に着目寸る視点で，大江の記述の思想の解 明を試みることとする。

\section{2. 用例にみる「うち」の意味}

\section{2-1.「うち」の呼称}

大江の「うち」を明らかにするにあたって，まず用例にみる「う ち」の意味に着目寸る。大江が「うち」の用例として，呼称に用い られる日本の「うち」の特殊性について述べている注19)。

われわれは日常「うち」という言葉をしばしば慣用するが，これ は単純に物の内外の呼称に用いられるだけでなく, 妻は第三者に 
対する場合自分の夫を指して「うち」と呼び, 関西では他人に対 して己を「うち」といい, 同族のものは身内と称される。また「う ちでは」というときは「私の家庭では」の意味と同時に,「うちは 何町, 何番地」という場合の家そのものの両方を指す。大方は木 一ムとレシデンスとが完全に使い分けられる国が多いのに, 日本 では, 家の中そのものが「うち」であり, 同時にその中で営まれ る家庭もまた同様に「うち」である。注20)

ここで大江は, 物理的意味としての(1)物の内外における「内」, 人間関係における呼称としての(2)第三者に対寸る場合の自分の夫, (3)他人に対しての己, (4)同族のものを表寸語として「うち」を捉え ている。また,「うち」は, (5)営まれる家庭, (6)家の中そのもの, の 両方の意味を同時に持つという特徴を持っている。このことから， 「うち」は, 物理的空間の内外や家の中そのものの意味と, 対社会 の人間関係の表現や家庭そのものの意味を含んでいることがわかる。

\section{2-2.「うち」と「内」}

大江の記述では, 平仮名表記の「うち」と漢字表記の「内」が, 括弧を用いて強調され, 意味の使い分けが意識されているものがみ られた。このことから,「うち」と「内」は異なる単語として扱い, 「らち」と「内」の意味や関係性を明らかにする。

元来「うち」という呼名は家総体を指すと同時に「内」にも通じ, 屋内をも含めての総称であるが, 日本では古来, 家の内と外との 密接な関係がきわめて重要視されてきた。特に玄関とか縁側のよ うに, 専ら人の出入りする部分は, 家の内・外を取り結ぶための 専用のスペースとして最も大切に取り扱われている。注211

「うち」は，「「内」にも通じ，屋内をも含めて」家総体を指すこ とから, 単に家の内部を指寸意味だけでなく, それ以外の事柄も含 まれているといえる。それに対して「内」は，玄関や縁側のスペー スを含んで「外」と取り結ばれ密接に関係するような, 具体的に家 の内外に関わる事柄として用いられる。

つまり,「うち」が家総体や「内」を含んで多義的な意味を持つこ とに対し,「内」は, 家屋やスペースの「内」といった, より限定的 な意味で用いられているといえる注22)。

また, 大江が玄関や縁側について述べていることにも着目すると, 「人」の出入りする空間が「内・外を取り結ぶ」とされており, こ のことから「うち」は，人の行為（出入または玄関での靴脱ぎ）の スペースによって取り結ばれた内・外であるということがいえる。

大江は, 人の行為の空間が内空間と外空間を結び「うち」となる という, 空間構成の仕方に現れる,「うち」の空間的側面を捉えてい た。「内」について, 次のような記述もみられる。

内空間の中核部を重厚に覆い包む大屋根は勾配なりに下降しつつ 下屋部分に及び, さらに外に向って深く張出された軒の出が丈の 高い垂壁の作用をともないながら, 内空間の外界からの独立性を 一層決定づけるようになる。(中略) 内外空間を分隔するために広 く用いられる一般的な手段は, 分厚い外壁と重厚な扉によるのが 普通である。しかし日本は建築の内外を分つのに, この一般的な 単純・直截の方法によらずに, ある複雑な空間的手法を選んだの
である。注23)

ここでは,「内」がより具体的な建築の例に用いられている。一般 的な「単純・直截の方法」による内空間は「分厚い外壁と重厚な扉 による」と述べられており, 物理的に壁や扉で囲まれた建物の内部 空間のことを指していることから，物理的「内」が引き出される。 しかし日本の「内」空間は,「複雑な空間的手法」によって分かたれ る。ここで内外を分けるための空間的手法は大屋根の深い軒下空間 (と高い垂壁)によって内外空間が分けられるというあり方である。 大江は，内外空間の間に空間を用いて内の「独立性を強める」（分け る）と理解していると同時に, 前の引用ではそのような空間が内外 を「取り結ぶ」空間としても捉えられていた。つまり，日本の複雑 な空間的手法は，「内」「外」の間に空間をはさむことで内外を隔て つつ, その空間に人の動き (出入)が含まれたときには内外を取り結 ぶことである。このことから,「うち」は, 内外の隔てと連続の両義 性を持った間の空間によって成立するといえる。

以上のことから, 「うち」は, 漢字表記の「内」と区別して用いら れつつ, 物理的空間を表す「内」も含んだ, 家総体を表す事柄とし て用いられており, 複雑な空間構成（取り結ばれることと隔てられ ることの両義性をもった空間）によって現れる総体であった。

また, 2-1 から, 呼称としての「うち」は, 人間関係の表現とし ての呼称であり, 己（主体）と, 己と親密な関係にある人（もの） との関係性において成立する「うち」であった。「うち」は，空間同 士の関係性である空間構成によって現れるものと, 主体との親密な 関係性としての人間関係によって呼称に表れるものであるといえる。 このことから,「うち」は，建築にかかわる事物的意味と，人間関係 に関わる共同存在的意味で用いられていた。

\section{2-3. 隔てと「うち」}

2-2 から, 「うち」は, 関係性に関わって, 複雑な空間構成手法を 用いることで日本独特のものとなることがわかる。複雑な空間構成 手法で重要なのは, 内と外の間に隔てと取り結びの両義性をもった 空間をとりいれることであった。以下の記述では,「隔て」の重要性 が述べられている。特殊な隔てのあり方が「うち」の特殊性を引き 出していることから,「うち」に関わる「隔て」注24)に着目する。

日本ばかりでなく東洋ではうちと外との分け隔ては, 家庭対社会 の意味においても，また家の内外の物理的意味においても同様に 極めて厳しい。注25)

ここでは, 日本 (東洋) で「うち」は, 外と厳しく分け隔てられ る事柄として大江に理解されていることがわかる。この隔ては, 2-1 で明らかになった, 人間関係の表現としての意味 (家庭対社会) と, 空間関係の表現としての意味（家の内外の物理的意味）の両方に共 通するものである。空間関係を表す「うち」の隔てについて, 日本 の家屋の構造に着目しながら述べられている記述がある。

経路を構成する空間配列は極めて流動的であり, 刻々に変転して ゆく。その経路も極めて柔軟であり，決して歩む人の身も心も拘 束することはない。人の心組もまたそれにつれて外界から内部一 と何の抵抗感も伴なわずに知らず知らずに溶け込み, 誘い込まれ てゆく。その経路を歩み終ったとき, 人は外界と完全に隔絶され 
た新しい世界に入ったことに気がつくはずである。幾重かに建具 が用いられることがあっても心理的にはほとんど無抵抗なスクリ ーンである。それにもかかわらずうちとそととの分離感は頑丈な 扉よりはるかに保たれ, さわがしい外界から隔離されて, そこに 安心して住まえるうちが成立するのである。注26)

ここで「うち」に関わる隔てとして「隔絶」「分離感」「隔離」が 挙げられる。ここで「隔絶」,「隔離」は, 経路性といわれるような, 流動的な空間的変化と時間的変化によって現れる安心して住まえる 「うち」の成立に必要な事柄であると理解できる。隔離は, 経路性 をもった空間配列による時間的・空間的な連続性によって構成され ることから, 分離と連続の両義性をもった隔てであると把握できる。 「分離感」は, 心理的に主体が感じる隔てのことである。「うち」は, 「そと」とも「うち」とも意識していなかった主体が，流動的で柔 軟な空間配列の経路（家屋における庭など）を歩むことで, 体も心 組みも徐々に「うち」へと溶け込み, 歩み終えたそこが「うち」で あると気が付いた瞬間に現れるものである。そして, 主体は,「うち」 が現れたとき，外（外界）と分離される。この気づきは，視覚的・ 物理的な頑丈さで現れるものではない。

このことから, 日本の家屋にみる「うち」の隔ては, 物理的・直 截的な物によるものではなく, 心理的・流動的な空間構成（経路性） と時間的連続性であり, 主体に現象する「うち」は, 新しい世界と して外界から箃しく隔てられたものになる。厳しい隔てによって確 立された「うち」は, 主体に「安心」をもたらし, その安心感があ るからこそ「住まえる」場所として, 安心して住まえる「うち」を 引き出すことができる。

経路では,「うち」における隔離が, 幾重かの「建具」という建築 の道具立てによって強化されることになる。これらの建具は, 物理 的強度はなく, 心理的にも「無抵抗なスクリーン」であると捉えら れている。主体にとって, 外との隔ては厳しいものでなければ安心 して住まえる「うち」にはならないが,「うち」に入ってしまえばそ こは安心して住まえる場所であるため,「うち」には強固な隔てが必 要ないのだ。「うち」の建具は, 物理的にも心理的にも無抵抗なもの として捉えられる。それは, 厳しく隔てられた「うち」への空間的 な信頼感や「うち」の共同存在としての家族（呼称に現れる）への 信頼感によるものであり, 建具の存在自体が,「安心して住まえる」 ことを象徵しているといえる。

また, 安心して住まえる「うち」が現れるための隔ての心理的変 化に重要な要素が, 次の記述から引き出される。

われわれは，それが如何に厳重に閉ざされていようとも，またそ の厚さが如何に厚からうともただ一重の扉だけが単純に家の内外 を隔離しているような入り方にはあき足らないのである。敷居一 本だけで外から中へ飛び込むような唐突さにはやり切れない思い をする。これは遠い昔から何代もの間われわれの血の中に，身体 の中に代々受け継がれ, 育てられて来た一つの貴重なタブーであ る。注27)

大江は, 心理的変化による隔てによって「うち」とそとが分けら れるというあり方を，「習慣」であると述べている注28)。この「習慣」
は, 個人の人生のうちに染みついた習慣の意味もあろうが，「遠い昔 から何代もの間われわれの血の中に，身体の中に代々受け継がれ」 や，「代々私達の中に浸みついており」という記述から，歴史的に身 体に刻み込まれたものであることがわかる。ここでいう「われわれ」 は，そういった「習慣」の中で生きてきた人々のことを指しており， ここでは日本の風土や文化の中に身を置いて生きてきた人々のこと であろう。土足でうちに侵入する嫌悪感は，日本人としての歴史的 な身体に「習慣」づけられた事柄の一部が久如することによって現 れる違和感であり，違和感を自覚できる身体だからこそ，「うち」が 現象してくると捉えられる。

つまり, 安心して住まえる「うち」は, 心理的変化を感じること ができる身体（ここでは日本人としての習慣を持った身体）があっ てはじめて，経路を歩む際の時間的・空間的連続性による隔てから 気づかれる事柄である。これは，日本人としての習慣を持った身体 が，行為と場所の意味を了解することで現象する事柄であると捉え ることができる。このことから，「うち」は，日本人の歴史的習慣を もった身体が，時間的・空間的連続性を持つ空間構成で行為するこ とで現れる隔てによって現象することであり，安心して住まえる場 所としての「うち」となることが引き出された。大江は, 経路性の 時間的・空間的な身体の体験を通して捉えられる心理的な距離感に よる隔てに安心性を見いだし,住まうことができる場所としての「う ち」にまで展開しているといえる。「安心して住まえる」ことの根底 は，歴史的な身体を持った主体が，玄関の空間や行為，経路性など に，隔ての意味を感じ取ることができるからこそ，外との㛜しい隔 てに安心感を持ち得ることにある。大江は，建築家として，建築を 制作寸る立場から，建築的に身体性という視点でもって，独自の「う ち」建築思想として展開していったといえよう。

\section{3.「うち」の位置づけ}

\section{3-1.「うち」と「間」}

安心して住まえる「うち」の成立には，日本人の身体を持った主 体の心理的変化を生むような複雑な空間構成が重要であった。この ような空間構成手法は, 大江の建築思想である「間」の構成と関係 していることがわかる記述がみられる。大江は,「間取り」について， 「間」を「取る」という言葉の意味に言及しており，日本における 「間」の重要性を述べている注29)。以下の記述から，「うち」のあり 方は，「間」と，建築的に深く関係していることがわかる。

日本の「うち」のデザインは決して固定固着されたものではない。 元来間取りは古くから補設（ふせつ）と呼ばれる可動のエレメン 卜によって構成され，間取りは間仕切りによって常に変転自在で ある。変転する相互の間には常にまた自ら一つ秩序の成立してい るその状態が間取りなのである。注30)

ここでの「うち」は，間取りを持った建物屋内のことを指し，デ ザインすることができる対象として捉えられる。日本の「うち」の デザインは,「可動のエレメント」によって構成され, 変転自在であ りながら秩序を持った「間」を有して成立している。「うち」は，流 動的な空間配列によって構成される柔軟性を持つ経路の構成であり, 固定の空間構成に縛られない変転自在性（流動性・柔軟性）を持つ 
という特徵があった。「うち」は,「間」取る空間構成によって, 時 間的・空間的に流動的でありながらも, 作法・秩序をもって律せら れ，構成された隔てによって成立するといえるだろう。

また「間」は，楽譜や決まった拍数があるわけでもないにもかか わらず, 寸分の狂いも許されない厳密な秩序をもって, 主体の肉体 で実在的に統一される事柄である注311。この「統一」は, 理で解す のではなく「直観」によって表現されることから, 感覚的な, 身体 に染みついた事柄として捉えられる。2-3では，「うち」の気づきに は日本の風土的習慣を持つ身体が必要であり, 時間的・空間的連続 性による隔てによって心理的に現象することが明らかになった。こ のことからも,「間」と「うち」の関係性は明らかである。日本の建 築特有の空間構成の根底を支える概念こそ「間」であり,「うち」は

「間」の構成によって現れる事柄であると引き出すことができる。

\section{3-2.「うち」と「心」}

先行研究注32)で, 大江の「間」の位置づけは, 近代建築に欠けて いる大切なこととして, 回復すべき事柄であり, 彼の建築制作にお いて久かすことのできない手法・精神であった。そして,「間」の構 成に最も大切にされたのは「心」であった。安心して住まえる「う ち」は, 身体を持った主体の心理的変化が重要であり, 「間」の構成 で現れることから，「心」との関係性をみていく。

こうしてみると庭の空間も部屋の空間も, 必ずしも別の空間では なく, むしろ「うち」を構成する一連の空間の一部であるとみる ことができる。こうした空間構成がわれわれの庭をデザインする 方法であり, 同時にそれがまた部屋部屋の間取りを構成する原理 なのである。ここに一貫して流れる構成の基本原理は, 人の歩む につれ, 心の移るにつれて同時に移り変ってゆく局面の変化に専 らその主点を置くのである。これこそ日本のデザインの秘密を解 く鍵である。したがって主題はビジュアルなフォルムやパターン にあるのではなく, あくまでも「心」の問題が第一義であり, 固 定的な意味での形の良し悪しはむしろ第二義的な比較的軽い要素 となる点が普通の単純なインテリア・デザインとは全く異質なと ころである。注 331

「うち」は, ある限定した内部空間を指すだけではなく, 様々な 空間によって構成された総体であった。その構成の原理は, 「人の歩 むにつれ, 心の移るにつれて同時に移り変ってゆく局面の変化に専 らその主点を置く」というような，「人の歩み」や「心の移り」によ って変化する局面を重要視した事柄である。大江は, その構成原理 によって「うち」までの経路を「間取る」ことで,「うち」を構成す ることが，日本のデザインにとって重要なことであると考えていた といえよう。建築において「心」は，目に見える要素（フォルム・ パターン) よりも優先されるべき事柄として挙げられ, 「うち」の構 成での鍵として, 非常に重要な事柄として位置づけられた。また, 「心」に関連する記述として，以下のような記述もみられた。

問題は住む人の生活の「心」に関する要素が軽視, あるいは時と して全く度外視されたまま家が作られてゆく点にある。道路が如 何に立派になろうと, 交通機関が如何にスピードアップされよう と, また冷暖房の効率が如何に高くなろうと, われわれの住居の
なかに起こる「心」の問題はむしろ逆になるのである。何世紀も の間, 住居のうち・そとで一番大切な要素として最も慎重に取り 扱われてきた「心」への関心が，ここで急速にぶちこわされてし まったことは，住宅対策を立てた為政者の責任というより，むし ろ建築家直接の大きな罪科である。注34)

大江は, 住居のうち・そとにおいて一番大切な要素を「心」であ ると捉えていた。この「心」は,「住む人の生活」に関わる事柄であ り, 住居のうち・そとで最も慎重に扱われる事柄であった。大江は, 「心」に関心を払った構成を「間」の構成としていたが注35), 現代 （当時 1962 年頃）の住宅建築にはこの「心」は欠けていて回復させ るべき要素であると捉えていた。そして, 大江は, 住まう人の「心」 に関心を払った住居を作ることが，建築家の責任であると捉えてい たこともうかがえる。間」の構成による場所は, 安心して住まえる

「うち」であり, 大江の目指す心゙き住まいの本質である。

\section{4. 大江宏の「うち」の構造}

2,3 章では, 大江の記述にみる「うち」に関する言説を, 前後 の文脈から分析し，その意味の特性と位置づけを明らかにしてきた。 以下のような「うち」の特徴が示された。

(1)「うち」は，呼称としての「うち」として，主体との親密な関係 を表す意味で用いられる, 共同存在的な側面が捉えられた。(2-1)

(2)「うち」は，物理的「内」の意味を含み，空間に関わって事物的 な側面をもつことが捉えられた。(2-2)

(3)「うち」は，身体の行為によって心理的に外界と分離・隔絶され た主体が, 気づくことで現象する安心して住まえる「うち」とし て捉えられ，現象的注36) な側面をもつことが捉えられた。「うち」 に気づくまでの隔ての現象は, 日本人としての習慣を持った身体 によって引き起こされる心理的変化によるものだった。(2-3)

(4)安心して住まえる「うち」とは, 隔てによって外界と隔絶された 「新しい世界」に入ることで生まれる安心感によって住まえるこ とが可能となった現象的な場所であることが引き出された。(2-3)

(5)安心して住まえる「うち」は，人の歩みや脱靴などの身体の行為 による心の移り変わりを最優先事項とする「間」の構成原理によ って成立していることが引き出された。(3-1)

(6)「うち」構成に非常に重要な鍵は, 「心」（目に見える要素よりも 優先されるべき事柄）であった。大江にとって安心して住まえる 「うち」は，目指す心゙き住宅のあり方であった。(3-2)

これらの特徴から, 以下のことが示された。

まず「うち」は，i，物理的「内」，ii．安心して住まえる「うち」, iii. 呼称としての「うち」の 3 つの意味を持っており, i は事物的 「うち」, ii は現象的「うち」, iii は共同存在的「うち」として捉え られた。次に,「うち」の成立には隔ての構造が重要であった。i は, 物理的・直截的な隔てによって成立し, iii は同族意識からくる隔て によって, そとからはっきりと分かれることであった。それに対し て, ii の隔ての構造は特徵的であった。ii の隔ての構造は, 日本人 の習慣をもった身体を土台とし, 主体が時間的・空間的に連続性・ 流動性をもった空間構成, 隔ての行為の場所を身体で体験し, その 中で起こる心理的変化を経て「うち」を自覚する（入ったと気づく） ことで「うち」が現れるというものであった。そのような隔ての構 


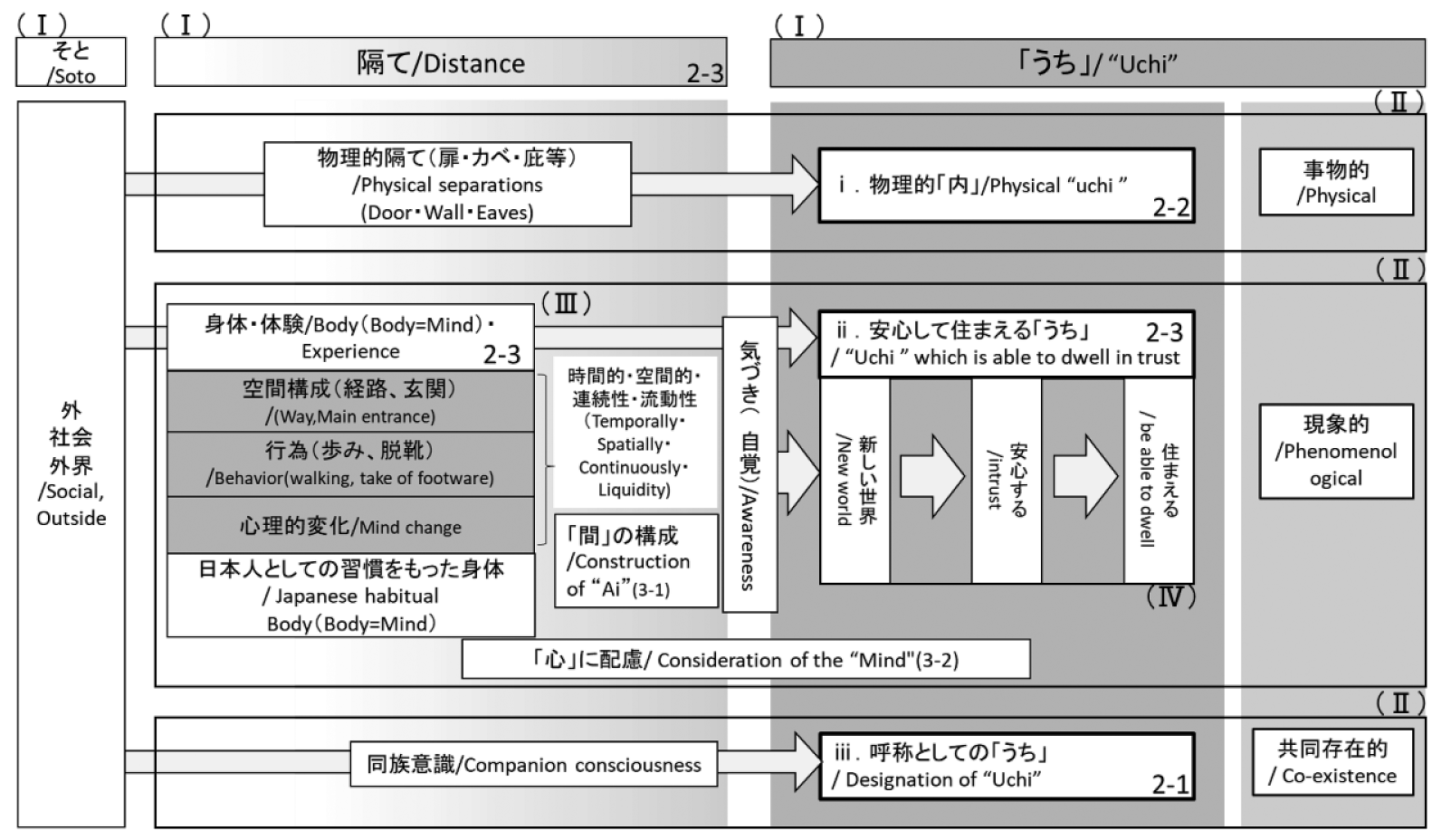

Fig.1 Structure about meaning of "Uchi" in Hiroshi Ohe's descriptions

成は, 大江の重要な建築思想である「間」の構造であり,「心」が最 も重視されるものであった。

明らかとなった大江の記述の「うち」に関する言説の特性を構造 化すると, Fig. 1のようになった。Fig. 1 では, （I ）「そと」から 「隔て」を経て「らち」に至る過程からそれぞれの特徴を整理し, 関係性を示している。矢印は, 「とと」から「うち」一至る過程を表 している。（II）「うち」は「隔て」の構成によって, あり方が異な ることから，i．物理的「内」とその隔ては事物的「うち」, ii. 安 心して住まえる「うち」とその隔ては現象的「うち」, iii. 呼称とし ての「うち」とその隔ては共同存在的「うち」として図に示した。 特に, ii の隔ての構成は, 日本の特殊な構造を持っていることから （III）日本人の習慣を持った身体を前提とした体験のあり方から「う ち」への自覚（気づき）があるという図と, その構成が「間」の構 成であることを,「隔て」の特徵として示した。また, ii の「安心」 して「住まえる」ことの根底には，「身体」の隔ての体験として「間」 の空間構成を歩み「新しい世界」へ入り，心理的に外界と峳しく隔 てられること生まれる「安心」という「心」の状態がある。(IV) 心 の「安心」によって「住まえる」（住まうことが可能な）場所として 「うち」が成立するという構造が引き出されたため, 図に示した。

「そと」と「隔て」とに関わる「うち」の構造は, 身体的（物理 的・精神的）の諸相すべてを含んだ「安心」という日本における住 まいの特質が表現されたもの注37) であると捉えられる。安心して住 まえる住まいとしての「うち」は，「やすらぐ」「安心してねむる」 注38) ことができる意味として，信頼して身を任せることができる場 所であるといえる。西洋では, 物理的な壁や屝によって外と鋭く切 り離されるが, 大江は日本における独特の複雑な空間構成によって, 隔てを捉えていた。本稿では, 大江の「うち」を, 安心して住まえ る場所として, 外の空間から隔ての空間構成で切り離された「うち」 を，日本の住まいの特質をあらわしていることと捉えた。

\section{5.おわりに}

本稿では，主題を大江宏の記述の「うち」に関する言説について とし, 大江の建築思想の一端である「うち」を, 大江の言説の解釈 から明らかにし，その構造と重要性を明らかにすることを試みた。 大江の「うち」は，事物的，現象的，共同存在的な意味をもち，日 本独特の隔ての構造によって現れることであった。安心して住まえ る「うち」を, 大江の目指すべき住まいのあり方として, 重要な建 築思想であると位置づけた。

大江は, 近代合理主義の中で失われた, 建築に重要なものを復権 させようと試みていたことから，日本独特の「うち」を自身の建築 論として展開し，住まうことの重要な意味を示していたといえる。

注

注1）以降本稿内で大江と表記した場合は，大江宏を指すこととする。

注2）『新建築 1995 年 12 月臨時増刊 [現代建築の軌跡], 新建築社, p. 290, 1995』に掲載される《大江宏の混在併存》では, 崔康勲氏により当時の社 会状況や建築界での議論について，以下のように示される。

「確かに当時は，1950 年代の戦後日本のモダニズムの実現，次いでその 展開をめぐる伝統論や空間論, 民衆論が建築家の意識を支配していた時 期であり，大江自身も埒外にいたわけではない。同級生である丹下健三 や浜口隆一の存在は近代主義と民族主義をめぐる論客として, むしろ積 極的な関心事であったはずである。にもかかわらず,そこにおける議論は 表層的であり，一過性のものにすぎないかのごとく大江には感じられて いた。伝統とか空間とか民衆とか，ひいてはモダニズムとは，その上う な表層的で，一過性の事象としてではなく，幾重にも歴史において浮上 してきたテーマであり，また将来においても問われ続けられねばならな いものである。」

注3）大江の経歴や，作品のリスト，写真，図面，紹介文等のデータについて は, 『別冊新建築：日本現代建築家シリーズ(8)大江宏』(新建築社, 1984.) 等に掲載されている。此等の書籍は, 大江の建築家としての考察に留まら ず, 出生や生い立ち, 生前をよく知る大江新氏や昭氏へのインタビュ一等, 多岐に及び，大江を全人格的に捉えようと試みられる。また，大江が建築 に関わり思考の地盤となると考えられる幼年期や少年時代を含む生立ちを 語った資料としては, 法政大学での最終講義である『建築と私』にて, 特 に示されており，講義の内容は，大江宏『大江宏＝歴史意匠論』（南洋堂， 
1984.）の第1章として収録されている。

注4)『大江宏 : 建築雑誌 vol. 100, No. 12301985 年 2 月号 p. 9』における「建 築作品の存在意義一昭和 30 年をかえりみて一」において, 大江は, 「近代 建築そのもの」に対してではなく,「純化の方向だけを先鋭に追求する」こ とに対する疑念を表明している。

注5）秦明日香, 河内浩志, 上野友輝：「大江宏の記述における「間」の言説 について」, 日本建築学会計画系論文集 83 (753)，2203-2210， 2018.

注6) (1)「間」の特徵が，時間的・空間的構成として捉えられている，(2)「間」 の特徵と建築とが，対応関係や手法をもって捉えられている，(3)「間」は， 主体である建築家の修練や行為に関わる繰り返しにより「習熟」される事 柄であり，修行のような形として大江は自覚している，という特徴が明ら かになった。

注7）「気配の美学」,「ものづくりの初心」には括弧の付かない「うち」が用 いられていた。両論考で抽出された「うち」は，本稿の 2-1で明らかにな る, 呼称としての「うち」の人間関係的意味として用いられていた。

注8）大江宏 : 『建築作法 混在併存の思想から』, 思潮社, 1989. 本書は, 大きく 5 章で構成されており, それぞれ, i. 手法としての「間」, ii. 能舞台と能楽堂, iii. 古典の創造的昇華, iv. 建築と文化, v. 併存混在 としての日本文化として題されている。1〜4章には出版までの 31 の論考 が大江の自選により再編成し, 纏められている。5 章には, 石井和紘氏に よる『新建築』でのインタビュー記事が掲載されている。

注9）大江宏 :『大江宏対談集 建築と気配』，思潮社，1989

本書は, 1973 年から 1985 年までに公開された 10 の対談や講演会の内容 が話し言葉で書き起こされ纏められた資料である。多くの雑誌等に散りば められた論考とは異なり, 纏まった形で彼の自身の建築思想を語った対談 が記録される類まれな資料である。このことは, 同書のあとがきにおいて, 息子である大江新氏により「即興的なやりとりの中から実に多くの潜在的 多様性が表出しているように思われます。」と指摘されている。

注10）外山滋比古:『日本の建築家 4 大江宏 間あいの創造』, 1985

注11）真木利江, 加藤駿 :「九十八䝿院の内外構成 : 大江宏建築作品における 「うち」の構成手法」, 山口大学工学部研究報告 59(2), 25-28, 2009.こ の研究で「うち」は, (1)屋根の重層性 (身舎一廂構成), (2)布置と地割, (3) 屋根・垂壁による断面構成という3 つの建築的構成によってつくられるこ ととして捉えられ, その 3 つの建築的構成を視点として, 大江の建築作品 である『九十八鼠院 (平櫛田中邸)』の全体の内外構成を図式的に分析し, 模式図的にまとめており，本研究にも示唆的である。

注12) 本稿で取り上げる引用文中の「うち」の表記の仕方として, 括弧の種 類，ルビの有無については文献での表記をそのまま採用している。

注13) 大江の記述は,『別冊新建築 : 日本現代建築家シリーズ(8)大江宏』(新 建築社，1984. ）に掲載される大江へのインタビュー記事「間と気配に基づ く空間構成」における前書きにおいて, 以下のように評価される。

「大江氏が自身の建築思想や設計法を，自ら手で記したものは少ない。 また，公の場でこういった私見を述べられることもまれである。したが って, 大江氏の建築に対する姿勢を探ろうとすれば,これまでの数少ない 発言や文章を通し，それらをつなぎ合わせて知る術とするしか方法がな い。しかし，大江氏は弟子や学生など若い人たちを交えた語らいの場で は，時として時間の経つのも忘れて饒舌に建築論を展開されるともいわ れている。」

このことからも，大江宏論を考察する上で，彼の残した記述を対象資料 とした研究は，十分に効果的であると考えられる。

注14）大江について, 建築論的な切り口で取り上げた文献として『建築論事 典』(日本建築学会編, pp. 136-137, 彰国社, 2008) が挙げられる。「大江 宏」の項目は，第二部「建築家の思想」において，崔康勲氏により，堀口 捨己との関係や，大江の近代（主義）建築に対する姿勢が記述される。

注15）「種別/Type」は主に著者を示す。著者は資料の奥付に従って記してい るが，複数人の場合は「共著」とした。

注16)「出版年」は論考初掲載年, 「掲載」は初掲載された書名, 「Table1」は Table 1 の著書との対応関係を示した。また, Table 2 の論考の抽出にお いて, 明らかに建築思想が引き出すことのできない「うち」(固有名詞に含 まれるものや単語として用いられないもの）は，対象から除外した。

注17）崔 康勲：「法政大学大学院」における「近代」の意味：建築家・大江 宏の言説に関寸る方法論的研究 その 1 , 日本建築学会計画系論文集 525 , pp. 307-312, 1999.

また, 他, 崔氏の研究として, 「「法政大学 58 年館」における「設計変更」 の意味：建築家・大江宏の言説に関する方法論的研究」をはじめ, 建築論研究会（代表 西垣安比古）：建築制作論の研究, 中央公論美術出版, pp. 533-555, 2016. 掲載，「建築術史の建築一術 - 考 一大江宏の場合一」 などが挙げられる。

注18）石井翔大, 種田元晴, 安藤直見 :「混在併存」を基軸とする大江宏の建築 観の変遷，日本建築学会計画系論文集 83 (746)，783-796， 2018.

注19）ここでの引用は, 靴のまま家に入る場合と, 必ず履物を脱ぐ場合とで, 家の造りようだけでなく，家に対する観念，家に対する感じ方が心理的に 根本から異質になることを提示する文脈による記述である。

注20）前出 7, p. 9, より「建築の本質」, 初出『建築文化』, 1962.9

注21）大江宏 : 建築作法 混在併存の思想から, p. 148, 思潮社, 1989. より「内 と外一浜田家三越店」初出『商店建築』, 1974.2 (原題「浜田屋・嵯峨野」) 注22）「うち」に関わって「内」に関しても，対象資料から悉皆的に記述を 収集・整理したところ，固有名詞に含まれる「内」を除き，若干の例外 (「内 在」「内面的」）はあるものの，そのほとんどが部屋や建物などの空間の内 部や内側を指す意味として用いられていた。

注23）大江宏 : 建築作法 混在併存の思想から, p. 24, 思潮社, 1989. より「書 院造と工匠の系譜」,初出『ディテール』, 1970.1

注24)ここで「隔て」という用語は, 大江の用いる「隔離」や「隔絶」,「分離」 といった用語の意味を包括する意味で筆者が用いている。

注25）前出 7, p. 9, より「建築の本質」, 初出『建築文化』, 1962.9 注26）前出 7, p. 10, より「建築の本質」, 初出『建築文化』, 1962.9 注27）前出 7, pp. 9-10, より「建築の本質」, 初出『建築文化』, 1962.9 注28）前出 7, p. 8, より「建築の本質」, 初出『建築文化』, 1962.9

靴脱ぎによる「うち」の心理的効果に「習慣」を持った身体が必要である ことは以下の大江の記述からわかる。

「私達は昔から履物を脱いで家に入る習慣を持っている。(中略) この習 慣は代々私達の中に浸みついており，ホテルの寝室のじゅうたんを靴の まま歩くのは何か土足で家へ押し上るような気がして理屈なしにいやな 気分である。」

この記述は，「うち」の言葉はないが，履物を脱ぐことへの言及であるこ とから，「うち」の成立に関わる記述であると捉えた。家に入る際の靴脱ぎ (「うち」の心理的効果を生む肉体的所作の例）は「習慣」であり，「代々 私達の中に浸みついて」いる身体的な事柄であることが重要であった。

注29）前出 7, pp.61-75, より「手法としての「間」」, 初出『KAWASHIMA』, 1985.6

注30）前出 7, p. 12, より「建築の本質」, 初出『建築文化』, 1962.9 注31）前出 7, p. 106, より「建築と作法」, 初出『建築文化』, 1961. 12 注32）秦明日香，河内浩志，上野友輝：「大江宏の記述における「間」の言説 について」，日本建築学会計画系論文集 83（753)，2203-2210, 2018. 注33）前出 7, p. 14, 上り「建築の本質」初出『建築文化』, 1962.9 注34）前出 7, p. 15, より「建築の本質」, 初出『建築文化』, 1962.9 注35）大江宏：大江宏対談集 建築と気配，思潮社，pp. 214-215，1989.にお いては，神代雄一郎との対談「日本の現代建築と木」にて，「あらゆる生活 面に〈間〉という概念がつねにあるんだけれども, そいつはまず心の問題, 心の中枢の中で，一番その〈間〉というものは実感されていて，そいつを いかにして表現として出すかという…‥」と記され，「間」という概念と 「心」の問題とが関連付けられる。

注36)「隔て」を現象的にとらえる見方は，玉腰芳夫がすでに行っている。玉 腰は,「隔てに於ける場所の構造」（玉腰芳夫：日本建築学会論文報告集第 235 号) にて, 源氏物語における隔ての現象について, 家屋の道具立てに 着目し，「隔てという現象空間から場所を解明する」ことを試みていた。玉 腰は, 源氏物語における隔ての現象を, 単なる隔ての道具の認知上の近さ 一遠さではなく, 「建物に住い込むという様態にあって, 可能性を見積もる という，常に潜在態からの現実化との関連のうちでの現象」であるとして いた。大江の「うち」の隔てに記述される状況とは異なるが，「隔て」は単 なる（物理的）距離ではなく, 主体の在り方における様態に関わって現象 することにおいて, 本稿に示唆的である。

注37）C. N. シュルツ, 加藤邦男 :『実存・空間・建築』, 鹿島出版会, p. 80, 1975. 「住居とは, 住まうことの構造を, 住居の物理的, 精神的諸相のすべてに よって表現するのである。」

注38） 0 ・F・ボルノウ, 大塚恵一 : 「人間と空間」, せりか書房, p. 176, 1976. 「眠りは，空間がもはや対象的に把握しうる諸事物の関連としては人間に 対立することのない状態として，あるいはむしろ，自己と世界との間にあ る緊張が完全に消滅している状態として考えられなければならないであろ う。そしてこのような状態は, 同時に, 一つの究極的なやすらぎの感情の 状態としても理解されうるであろう。」 


\section{Asuka HATA ${ }^{* 1}$, Hiroshi KOUCHI ${ }^{* 2}$, Yuki UENO ${ }^{* 3}$ and Ai TOMIHISA *4}

\footnotetext{
${ }^{* 1}$ Assist. Prof., National Institute of Technology, Ishikawa College, M.Env ${ }^{*}$ Prof., Dept. of Architectural Design, Hiroshima Institute of Technology, Dr.Eng.

${ }^{* 3}$ Assist. Prof., Dept. of Architectural Design, Hiroshima I.T., Dr.Eng.

${ }^{* 4}$ Doctoral Student, Graduate School of Engineering, University of Fukui, M.Env.
}

\section{Introduction}

The purpose of this paper is to clarify the descriptions of Hiroshi Ohe's "Uchi". In this research, we focused on the descriptions about Ohe's "Uchi" and structured the meanings through analysis and interpretation of their descriptions.

\section{The meaning of "Uchi" in examples}

At first, "Uchi" has the meanings which is "uchi(written in Chinese characters )", and it is divided into "Physical meanings" and "Human relations meanings". The "uchi" often used to refer to the physical interior of a house or space. The phenomena that can be noticed by the Body (Body=Mind) walking along the route have the meaning of "Uchi" which is able to dwell in trust. "To be able to dwell in trust" is to feel the sense of distance in the spatial behaviors and pathways of the entrance, and to gain a sense of security isolated from the outside.The phenomena until notice "Uchi" were due to psychological changes caused by the Japanese habitual Body(Body=Mind).

\section{Positioning of "Uchi"}

"Uchi" is a matter which established by the construction principle of "Ai", which places the top priority on the change of people's process and mind. What is important in the composition of "Uchi" is the "Mind", and it is as a matter that should be prioritized over visible elements (Form • Pattern). The location of the "Ai" configuration is the "Uchi" which is able to dwell in trust. That is the essence of the dwelling that Ohe should aim for.

\section{Hiroshi Ohe's structure of "Uchi"}

There were three meanings of "Uchi”, “i .Physical "uchi'”, "ii . 'Uchi' which is able to dwell in trust", and "iii. Designation of 'Uchi'”. "i .Physical 'uchi' "was also used for the spatial of architecture and had a physical meaning. In order to establish "Uchi", the way of distance was important. The distance necessary for the establishment of "ii . 'Uchi' which is able to dwell in trust" is based on a body that has a custom as a Japanese. The phenomenon occurred by experiencing mind changes caused by actions (Walking, Take off footware) in complex space configurations (Way/ Entrances).

Because of the distance, "Uchi" becomes "Uchi" which is able to dwell in trust. The space composition for distance which required for the establishing process of "Uchi" which is able to dwell in trust is composed by the "Ai" method. Physical "uchi" is established by physical distance, and designation of "Uchi" is established by distance from companion consciousness. These structures of "Uchi" is shown from the fact that it was pulled out. The structure of "Uchi", which is related to Soto and Separation, is expressed as a characteristic of Japanese housing called "in trust" that includes all Body-Mind (physical and mental) aspects.

\section{Conclusion}

The subject of this paper is to clarify "Uchi" in the description of Ohe Hiroshi, and by organizing, analyzing and interpreting the target documents, the meaning of discourse of "Uchi" in the description by Hiroshi Ohe and which structure is clarified whether it is caught with such a spread. In this paper, we positioned "Uchi" which is able to dwell in trust in Ohe's architectural philosophy as the nature of Japanese dwelling. 